\title{
Study about Effect of Processed Biodiesel in Physicochemical Properties of Mixtures with Diesel Fuel in order to Increase their Antifouling Action
}

\author{
C.G. Tsanaktsidis, S.G. Christidis and G.T. Tzilantonis
}

\begin{abstract}
In this paper we try to study how processed biodiesel (with hydrophilic polymer) influences the physicochemical properties of their mixtures with diesel fuel. Using specific volumes of these mixtures, we determine humidity, density, kinematic viscosity and heat of combustion in order to investigate the effect of the polymer. The results show that humidity and kinematic viscosity could decrease considerably, so that mixtures of diesel and processed biodiesel become less pollutant to the environment than Diesel fuel.
\end{abstract}

Index Terms-Antifouling Action, Mixtures of Diesel with Biodiesel, Processed Biodiesel, Physicochemical Properties.

\section{INTRODUCTION}

The emergence of biodiesel as an alternative energy source in the modern era has been well rendered as the principal field of effort in both the academic sector and the sector of production. What is of particular importance in this effort is to certify the appropriateness of the end product in order that its use is beneficial in terms of energy as well as friendly to the environment. The quality testing of liquid alternative fuels principally aims at ascertaining to what extent the fuel is suitable in order to ensure the reduction of environmental pollution, the sound operation of the combustion machine and the highest work output through its use. The qualitative testing is expressed by a series of natural, chemical properties or other parameters, whose values are determined by the specific specifications these fuels should meet. The proposed methods of analysis are based on the general directions set by ASTM (American Society for Testing Materials) testing process as well as I.P. (Institute of Petroleum).

Specific laboratory exercises for the analysis of fuel properties are presented, which concern the determination of humidity, measurement of density, measurement of kinematic viscocity and determination of heat of combustion. However, the most important factors during the combustion of biodiesel or their mixtures with diesel are humidity and kinematic viscosity. Humidity because it causes corrosion, can cause ice blockage in the power grid that can be formed in low temperatures and last it can be

Laboratory of Qualitative Fuel Control

Department of Pollution Control and Technologies/ 2Department of Financial Applications

Technological Education Institute of Western Macedonia, Kila, Kozani -Greece 50100 divided during the warming-up and cause flame extinguishing from the produced steam (water vapour) and kinematic viscosity, because it determines the degree of scattering of fuel.

In this paper we study how the conformation of the hydrophilic polymer via charged groups and dynamic absorption of water molecules (because we expect the polymer to retain these molecules) ${ }^{[10,13]}$, influences the physicochemical properties of mixtures of diesel with processed biodiesel which have significant role in qualitative control of current fuels and their behaviour during combustion. For this aim we introduce in different samples of biodiesel the hydrophilic polymer TPA for forty five (45) minutes and the filtered is mixed with diesel. It is stressed that the volume of the biodiesel and the mass of the polymer maintain stable.

\section{Production ANd Physicochemical Properties OF BIODIESEL}

\section{A. Production of biodiesel.}

Biodiesel is produced by transesterifying the parent oil or fat with an alcohol, usually methanol, in presence of a catalyst, usually a strong base such as sodium or potassium hydroxide, or, preferably and increasingly more commonly, alkoxides. The resulting product therefore can contain not only the desired alkyl ester product but also unreacted starting material, residual alcohol, and residual catalyst. Glycerol is formed as by-product and separated from biodiesel in the production process, however, traces there of can be found in the final biodiesel product.

The biodiesel which use in this study is produced by $95 \%$ soyaoleum and coleseed and 5\% waste frying oils from houcehold

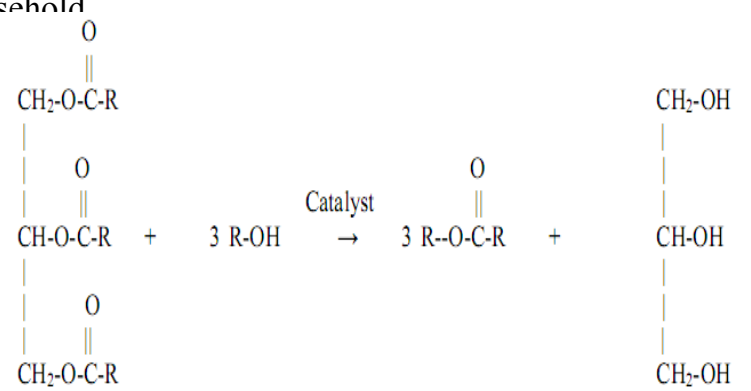

Fig 1. Transesterification Reaction ${ }^{[15]}$.

B. Physicochemical properties of biodiesel.

After the production of biodiesel, we have to certify the appropriateness of the end product measuring its physical 
properties and compare their vales to its specifications. For example, biodiesel can absorb a certain amount of water during storage. Such issues are addressed in biodiesel standards.

Some specifications in biodiesel standards are carryovers from petrodiesel standards. However, not all test methods carried over from petrodiesel standards into biodiesel standards are well suited for biodiesel analysis.

Although there are many standard methods used for analyzing the various properties, emphasis is placed on methods determined in our laboratory.

TABLE I. PHySiCOCHEMICAL PROPERTIES OF BIODIESEL (EUROPEAN BIODIESEL STANDARDS EN 14214 FOR VEHICLE USE). ${ }^{[14]}$

\begin{tabular}{|c|c|c|}
\hline \multirow{2}{*}{ Physicochemical Property } & \multirow{2}{*}{ Biodiesel } & $\begin{array}{c}\text { Methods of } \\
\text { Determination }\end{array}$ \\
\hline & & ASTM \\
\hline Density $15^{\circ} \mathrm{C}, \mathrm{g} / \mathrm{mL}$ & $\begin{array}{c}0.860- \\
0.900\end{array}$ & $\begin{array}{l}\text { ASTM D1298 - } \\
99(2005)^{[7]}\end{array}$ \\
\hline $\begin{array}{c}\text { Kinematic Viscosity, }\left(40^{\circ} \mathrm{C}\right) \\
\mathrm{mm}^{2} / \mathrm{s}(\mathrm{cSt})\end{array}$ & $1.9-6.0$ & D $445-06^{[8]}$ \\
\hline Humidity, $\mathrm{mg} / \mathrm{kg}$ & $<500$ & D 1744-92(2000) $)^{[5]}$ \\
\hline Heat of Combustion, $\mathrm{kJ} / \mathrm{g}$ & $>35$ & D 4809-09a $\mathrm{a}^{[9]}$ \\
\hline
\end{tabular}

\section{Physicochemical Properties Of Diesel Fuel}

The diesel oil constitutes mixes of many hydrocarbons with different properties. Diesel of internal combustion should have attributes that ensure auto ignition of fuel and furthermore sure and smooth combustion without problems in the conditions of booth combustion. The properties of fuel depend on the type of hydrocarbons that it contains, as well as from their contents. The Greek specifications of fuel Diesel have as objective the satisfaction of following properties.

TABLE II. GREEK SPECIFICATIONS (ENARMONIZED WITH EUROPEAN COMMUNity) OF PHYSICOCHEMICAL PROPERTIES AND THEIR METHODS OF DETERMINATIONOF DIESEL FUEL (FEK 332/B/11-2-2004, EN 590:1999).

\begin{tabular}{|c|c|c|}
\hline \multirow{2}{*}{ Physicochemical Property } & \multirow{2}{*}{ Diesel } & Methods of Determination \\
\cline { 3 - 3 } & & ASTM \\
\hline Density $15^{\circ} \mathrm{C}, \mathrm{g} / \mathrm{mL}$ & $0.820-0.845$ & ASTM D $1298-99(2005)^{[7]}$ \\
\hline Kinematic Viscosity, $\left(40^{\circ} \mathrm{C}\right) \mathrm{mm}^{2} / \mathrm{s}(\mathrm{cSt})$ & $2.00-4.50$ & D $445-06^{8]}$ \\
\hline Humidity $\mathrm{mg} / \mathrm{kg}$ & $<200$ & D $1744-92(2000)^{[5]}$ \\
\hline Heat of Combustion, $\mathrm{kJ} / \mathrm{g}$ & $>42.600$ & D $4809-09 \mathrm{a}^{[9]}$ \\
\hline
\end{tabular}

The various damage $\varsigma$ which water can causes, in farther treatment of fractions of oil, can be summarise in the followings; corrosions of various elements of units andobstructions of pipings and pumps, mainly in the ovens of distillation.

\section{EXPERIMENTAL PROCESS}

\section{A. Synthesis of Hydrophilic Polymer, Thermal Polyaspartate Anion (TPA).[1,2,3,11,12]}

The composition polymer course is held through the condensation of D, L aspartatic acid -one of the twenty or so common amino acids found in proteins- (1.5g) towards the equivalent polysouccinimide and the hydrolysis of the latter towards the final product of this reaction, the polyaspartate ion (TPA) $)^{[4]}$.

The selection of aspartic acid as a raw material was supported by the variation of humidity degree that these particle groups show in a water environment. ${ }^{[10]}$

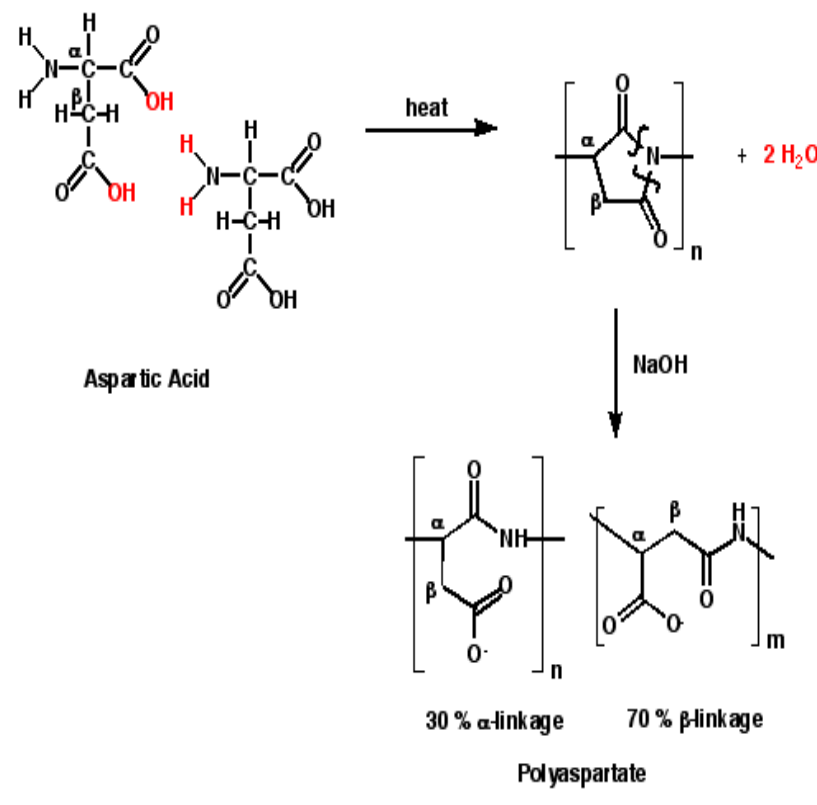

Fig 2. Synthesis of Hydrophilic Polymer, Thermal Polyaspartate Anion (TPA).

B. Humidity Elimination of biodiesel via TPA and Effect in other Physicochemical Properties.

At first the values of physicochemical properties of Biodiesel are determined with the ASTM methods and the appropriate equipment.

Next, $0.1 \mathrm{~g}$ of TPA is introduced in $20 \mathrm{~mL}$ volume samples of Biodiesel. Then, TPA is eliminated through filtration $^{[6]}$.

It must be referred that $20 \mathrm{~mL}$ is the demanded quantity of biodiesel for the specific measurements, while the quantity $0.1 \mathrm{~g}$ of polymer is defined from the limits of chemical additives in liquid fuels which is $1-4 \mathrm{Kg} / \mathrm{tn}$. The results are presented in below Table III and it is noticed that the use of polymer does not influence the physicochemical behaviour of fuel except humidity, so that it can be used further.

TABLE III. VALUES OF PHYSICOCHEMICAL PROPERTIES AND THEIR METHODS OF DETERMINATION OF BIODIESEL.

\begin{tabular}{|c|c|c|c|}
\hline $\begin{array}{c}\text { Physicochemical } \\
\text { Property }\end{array}$ & $\begin{array}{l}\text { Laboratory } \\
\text { Value } \\
\text { (Biodiesel) }\end{array}$ & $\begin{array}{c}\text { Laboratory } \\
\text { Value } \\
\text { (Biodiesel with } \\
\text { TPA) after } 45 \\
\text { minutes }\end{array}$ & $\begin{array}{c}\text { Methods of } \\
\text { Determination }\end{array}$ \\
\hline $\begin{array}{l}\text { Density at } 15^{\circ} \mathrm{C}, \\
\qquad \mathrm{g} / \mathrm{mL}\end{array}$ & 0.864 & 0.860 & $\begin{array}{c}\text { ASTM D1298 - } \\
99(2005)^{[7]}\end{array}$ \\
\hline $\begin{array}{c}\text { Kinematic } \\
\text { Viscosity, }\left(40^{\circ} \mathrm{C}\right) \\
\mathrm{mm}^{2} / \mathrm{s}(\mathrm{cSt})\end{array}$ & 4.68 & 4.51 & $\begin{array}{c}\text { ASTM D445 - } \\
06^{[8]}\end{array}$ \\
\hline Humidity, mg/kg & 298 & 240 & $\begin{array}{c}\text { ASTM D } \\
1744- \\
92(2000)^{[5]} \\
\end{array}$ \\
\hline $\begin{array}{c}\text { Heat of } \\
\text { Combustion, } \mathrm{kJ} / \mathrm{g}\end{array}$ & 38.573 & 38.571 & $\begin{array}{c}\text { ASTM D 4809- } \\
09 \mathrm{a}^{[9]}\end{array}$ \\
\hline
\end{tabular}




\section{Humidity Elimination of Mixtures of Diesel with Biodiesel and Effect in other Physicochemical Properties.}

Firstly, $20 \mathrm{~mL}$ of diesel is mixed with $5 \mathrm{~mL}$ of Biodiesel in order to determine (using the the ASTM methods), density, humidity, kinematic viscocity and heat of combustion.

Secondly, $20 \mathrm{~mL}$ of diesel is mixed with $5 \mathrm{~mL}$ of filtrate biodiesel (after the introduction of the hydrophilic polymer and the determination of humidity) and afterwards the same parameters are determined.

It must be referred that this mixture (in proportion $80 \%$ diesel-20\% biodiesel) had been chosen in order to investigate if it satisfies the Greek and the European specifications for diesel fuel (EN590) and if it is appropriate for use.

The results are presented in below Table III and it is noticed that the use of polymer does not influence the physicochemical behaviour of fuel except humidity and kinematic viscosity.

TABLE IV. VALUES OF PHYSICOCHEMICAL PROPERTIES AND THEIR Methods of Determination OF MiXTURES OF DieSEL WITH BIODIESEL $(80 \%-20 \%)$.

\begin{tabular}{|c|c|c|c|}
\hline $\begin{array}{c}\text { Physicochemical } \\
\text { Property }\end{array}$ & $\begin{array}{l}\text { Laboratory } \\
\text { Value } \\
\text { [Mixture } \\
\text { Diesel } \\
(80 \%) \text { with } \\
\text { Biodiesel } \\
(20 \%)]\end{array}$ & $\begin{array}{l}\text { Laboratory } \\
\text { Value } \\
\text { [Mixture } \\
\text { Diesel } \\
(80 \%) \text { with } \\
\text { filtrate } \\
\text { Biodiesel } \\
(20 \%)]\end{array}$ & $\begin{array}{c}\text { Methods of } \\
\text { Determination }\end{array}$ \\
\hline $\begin{array}{l}\text { Density at } 15^{\circ} \mathrm{C} \\
\mathrm{g} / \mathrm{mL}\end{array}$ & 0.823 & 0.821 & $\begin{array}{l}\text { ASTM D1298 } \\
-99(2005)^{[7]}\end{array}$ \\
\hline $\begin{array}{c}\text { Kinematic } \\
\text { Viscosity, }\left(40^{\circ} \mathrm{C}\right) \\
\mathrm{mm}^{2} / \mathrm{s}(\mathrm{cSt}) \\
\end{array}$ & 4.02 & 3.84 & $\underset{06^{[8]}}{\text { ASTM D445 - }}$ \\
\hline Humidity, mg/kg & 123.4 & 77.1 & $\begin{array}{c}\text { ASTM D } \\
1744- \\
92(2000)^{[5]} \\
\end{array}$ \\
\hline $\begin{array}{c}\text { Heat of } \\
\text { Combustion, } \mathrm{kJ} / \mathrm{g}\end{array}$ & 43.736 & 43.730 & $\begin{array}{c}\text { ASTM D } \\
4809-09 \mathrm{a}^{[9]}\end{array}$ \\
\hline
\end{tabular}

\section{Conclusions}

According to the above procedure we realize that it is possible to eliminate humidity and the values of humidity and kinematic viscosity in biodiesel with polymer of TPA have been decreased in forty five (45) minutes are of about $20 \%$ and $4 \%$ equivalently (Table III).

Firstly, the values of the mainer physicochemical properties of biodiesel of Table III have shown, that the produced biodiesel with or without TPA met the specifications of the standard (Table I) EN14214 (2003). Comparing values of physicochemical properties of density and heat of combustion (Tables I-III) we realize that they are not influenced by the use of the polymer.

Secondly, the values of Table IV have shown, that mixture of diesel with filtrate biodiesel have less water and lower kinematic viscosity than the other with simple biodiesel(about $38 \%$ and 4,5\% equivalently).

Furthermore, it is noticed that the two mixtures of diesel with biodiesel (80\%-20\%) met the Greek specifications (Tables II-IV) (FEK 332/B/11-2-2004, EN 590:1999).

This means that we can have in bigger degree conditions of better combustion of mixtures with result the improvement of their antipollution behaviour, because density an especially heat of combustion aren't influenced by the process with the hydrophilic polymer (Tables II-IV).

The result of elimination of humidity and the values of the other physicochemical properties from this mixtures, gives the possibility to be rendered as antipollution, because such blends can generally be used in existing oil heating systems and diesel engines without modification, and it can be distributed through existing diesel fuel pumps. This is an advantage over other alternative fuels, which can be expensive to use initially due to high cost of equipment modifications or new purchases.

In addition the lubricating effects of the biodiesel may extend the lifetime of engines.

\section{REFERENCES}

[1] The Presidential Green Chemistry Challenge Awards Program: Summary of 1996 Award Entries and Recipients; EPA744-K-96001;U.S. Government Printing Office: Washington, DC, 1996.

[2] J. Clark and D. Macquarrie Handbook of GREEN CHEMISTRY AND TECHNOLOGY 2002.

[3] Wheeler, A.P, Koskan L.P "Large scale thermally synthesized polyaspartate as a substitute in polymer applications" Mat. Res. Soc Symp. Proc, 1993, 292,277.

[4] J. Mosig, C.H Gooding, A.P Wheeler, "Kinetic and thermal characterization on the hydrolysis of polysuccinimide" Ind. Enf. Chem. Res. 1997. 36. 2163-2170.

[5] ASTM D1744-92 Standard Test Method for Determination of Water in Liquid Petroleum Products by Karl Fischer Reagent (Withdrawn 2000).

[6] ASTM D2276 - 06 Standard Test Method for Particulate Contaminant In Aviation Fuel by Line Sampling, 2006.

[7] ASTM D1298 - 99 (2005) Standard Test Method for Density, Relative Density (Specific Gravity), or API Gravity of Crude Petroleum and Liquid Petroleum Products by Hydrometer Method.

[8] ASTM D445 - 06 Standard Test Method for Kinematic Viscosity of Transparent and Opaque Liquids (and Calculation of Dynamic Viscosity).

[9] ASTM D4809 - 09a Standard Test Method for Heat of Combustion of Liquid Hydrocarbon Fuels by Bomb Calorimeter (Precision Method).

[10] A.N.Troganis, C.Tsanaktsidis and I.P. Gerothanassis, 14N NMR relaxation times of several protein amino acids in aqueous solutioncomparison with $17 \mathrm{O} \mathrm{NMR}$ data and estimation of the relative hydration numbers in the cationic and zwitterionic forms, J. Magn.Reson. 2003,164, 294.

[11] C.G. Tsanaktsidis, N. Sariannidis and S.G. Christidis, "Regression Analysis about Humidity Elimination from Diesel Fuel Via Bioorganic Compounds to Increase Antifouling Action". Proceedings of International Joint Conferences on Computer, Information, and Systems Sciences, and Engineering (CISSE 09) December 4-12, 2009 Vol 1: Technological Developments in Networking, Education and Automation.

[12] Helmut H. Brugman, SurTech Corporation; Vincent F. Hock, US Army $\backslash$ ERDC-CERL Demonstration of Green Chemistry at a Military Base Cooling Tower CORROSION 2004, March 28 - April 1, 2004 , New Orleans, La

[13] Stacey A. Palasek, Zachary J. Cox, Jonathan M. Collins (2007). Journal of Peptide Science 13 (3): 143-148.

[14] Gerhard Knothe Analyzing Biodiesel: Standards and Other Methods Review JAOCS, Vol. 83, no. 10 (2006).

[15] J.Van Gerpen, B. Shanks, R. Pruszko, D. Clements and G. Knothe Biodiesel Production Technology July 2004 NREL/SR-510-36244. 